\title{
Postdissectiós aortaaneurysma endovascularis kezelése „candy-plug” technikával perzisztáló állumen esetén
}

\author{
Hidi László dr. - Csobay-Novák Csaba dr. - Juhász Viktória dr. \\ Suhai Ferenc dr. - Szeberin Zoltán dr. - Sótonyi Péter dr. \\ Semmelweis Egyetem, Városmajori Szív- és Érgyógyászati Klinika, Érsebészeti Tanszék, Budapest
}

\begin{abstract}
Teljes aortára kiterjedő, A-típusú dissectio miatt Bentall-mútéten, mellkasi aortoaorticus interpositum implantáción és mellkasi sztentgraftbeültetésen átesett 79 éves férfi betegnél perzisztáló állumen miatt kialakult, krónikus, 60 mm-es, thoracoabdominalis postdissectiós aortaaneurysma megoldásaként, hazánkban először, az ún. „candy-plug” technikát alkalmaztuk. Az aortadissectio proximalis berepedésének lefedésével az endovascularis mellkasi aortarekonstrukció (TEVAR) elősegíti az állumen thrombosisát és az aorta remodellálódását, a thrombosis azonban gyakran - az esetek kb. 60\%-ában - csak részleges, és az állumen keringése a TEVAR mellett is fennmaradhat. Ezekben az esetekben az aorta további jelentős tágulásával kell számolnunk, amely gyakran csak nagy kockázatú nyitott mútéti vagy endovascularis beavatkozásokkal kezelhető. Ezeknek az eseteknek a biztonságosabb megoldása érdekében fejlesztették ki a standard TEVAR és az állumen zárását szolgáló módszerek kombinációját. Ilyen új eljárás az esetünkben is alkalmazott „candy-plug” technika, amely minimálinvazív úton megszüntetve az állumen keringését és megállítva ezzel az aneurysma progresszióját, hatékony és biztonságos megoldást jelenthet az aortadissectiók késői szövődményeként megjelenő postdissectiós aortaaneurysmák ellátásában.
\end{abstract}

Orv Hetil. 2020; 161(11): 437-439.

Kulcsszavak: dissectio, postdissectiós aneurysma, sztentgraft, endovascularis beavatkozás

\section{Endovascular treatment of the persistent false lumen of post-dissection aneurysms with "candy-plug" technique}

\begin{abstract}
A 79-year-old male patient was operated with Bentall procedure, thoracic aorta-aortic interposition and stent graft implantation for aortic dissection type A. Because of the persistent false lumen a chronic, $60 \mathrm{~mm}$ thoraco-abdominal post-dissection aortic aneurysm developed, which we managed with a new endovascular treatment, the so-called "candy-plug" technique. Thoracic endovascular aortic repair (TEVAR) can induce the thrombosis of the false lumen and the aortic remodelling via the covering of the proximal intimal tear. However, the thrombosis of the false lumen is often - in $60 \%$ of the cases - incomplete. In these cases we have to prepare for the persistent expansion of the aorta, which can be managed only with high-risk open or endovascular repair. Hence a new solution with lower risk was investigated, which combines TEVAR and the false lumen closure devices. Such a new treatment is the "candyplug" technique, which was performed in our case. This minimally invasive technique, which excludes the circulation of the false lumen and stops the progression of the aneurysm expansion, can be an effective and safe solution for the treatment of the chronic post-dissection aortic aneurysms.
\end{abstract}

Keywords: dissection, post-dissection aneurysm, stent graft, endovascular procedure

Hidi L, Csobay-Novák Cs, Juhász V, Suhai F, Szeberin Z, Sótonyi P. [Endovascular treatment of the persistent false lumen of post-dissection aneurysms with "candy-plug" technique]. Orv Hetil. 2020; 161(11): 437-439.

(Beérkezett: 2019. október 14.; elfogadva: 2019. december 10.) 


\section{Rövidítések}

CTA $=$ (computed tomography angiography) komputertomográfiás angiográfia; TEVAR = (thoracic endovascular aortic repair) mellkasi endovascularis aortarekonstrukció

Az elmúlt évtizedekben a B-típusú aortadissectiók ellátásában a jelentős perioperatív morbiditással és mortalitással járó nyitott mútéti technikák szerepét a kisebb megterheléssel járó endovascularis mellkasi aortarekonstrukciók (TEVAR) vették át [1]. A proximalis berepedés lefedésével a TEVAR a véráramlást a valódi lumen felé terelve elősegíti az állumen thrombosisát [2], teljes elzáródás azonban csak az esetek 40\%-ában jön létre [3]. A distalis berepedési hely, valamint a segmentalis és bronchialis arteriák felöli visszaáramlás miatt a thrombosis gyakran csak részleges, és az állumen keringése a TEVAR mellett is fennmaradhat [4]. Ezekben az esetekben a betegek 30\%-ánál az aorta további tágulásával kell számolnunk, amely akár újabb endovascularis vagy mútéti megoldást igényelhet [5]. Amennyiben van rá lehetőség, az állumen direkt embolisatiójával stabilizálható a dissectio, az esetek jelentős részében azonban szignifikáns méretű tágulat, ún. postdissectiós aneurysma jön létre [6], amelynél a fenti megoldás már nem hatékony. A fenesztrált sztentgraft ilyen esetekben megoldást jelenthet, alkalmazása azonban magas technikai jártasságot igényel, és a gerincvelői ischaemia kialakulásának kockázata jelentős [7]. Ezért azokra az esetekre, amelyeknél a postdissectiós aneurysma csak a distalis aortaívet vagy a mellkasi aortát érinti, kevésbé komplex, a gerincvelő keringését kevésbé veszélyeztető endovascularis eljárásokat dolgoztak ki, amelyek a standard TEVAR-t és az állumen zárását szolgáló módszereket kombinálják. Ilyen új eljárás az esetünkben is alkalmazott „candy-plug” technika $[8,9]$, amely minimálinvazív úton megszüntetve az állumen keringését és megállítva ezzel az aneurysma progresszióját, hatékony és biztonságos megoldást jelenthet az aortadissectiók késői szövődményeként megjelenó postdissectiós aortaaneurysmák ellátásában.

A 79 éves, hypertoniás, beszúkült vesefunkciójú, szívelégtelen férfi beteg 2000-ben Stanford A-típusú aortadissectio miatt Bentall-mütéten, majd 4 évvel később az aorta descendens proximalis részének postdissectiós aneurysmája miatt aortoaorticus Dacron interpositum beültetésen esett át. 2015-ben kifejezett háti fájdalom hátterében az aortoaorticus graft distalis végétől a zsigeri ágakig terjedő dissectio igazolódott. A progrediáló radiológiai kép miatt sürgető mellkasi sztentgraftbeültetést végeztünk a korábbi interpositumtól a truncus coeliacusig. A beavatkozás bár megállította a dissectio akut progresszióját, és stabilizálta a valódi lument, az aorta descendens középső szakaszától az állumen keringése továbbra is fennmaradt. Kontroll-CT-angiográfiás (CTA-) felvételeken a distalis mellkasi aorta és a rekeszszárak közötti aortaszakasz növekvő, $60 \mathrm{~mm}$ legnagyobb átmérőjü postdissectiós aneurysmája ábrázolódott (1., 2. ábra).

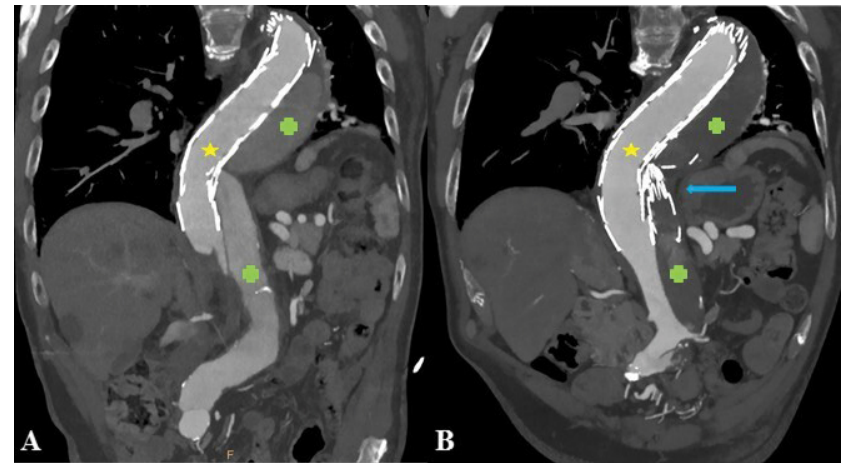

1. ábra

CTA a „candy-plug” beültetés előtt (A) és 9 hónappal a beültetés után (B). Sárga csillag - valódi lumen; zöld kereszt - állumen; kék nyíl - „candy-plug” záróeszköz

$\mathrm{CTA}=$ komputertomográfiás angiográfia

Tekintettel a beteg életkorára, kórtörténetére, társbetegségeire és a jelentős méretű postdissectiós aneurysmára, az állumen endovascularis úton történő zárása mellett döntöttünk. Erre a célra a 2013-ban Kölbel által leírt ún. „candy-plug” technikát választottuk [9]. Bal lágyéki feltárásból és a jobb arteria femoralis percutan punkciójából a valódi lumenbe, a korábbi thoracalis sztentgraft meghosszabbításaként, átfedéssel, egy $42 / 38 \times 158$ mm-es Zenith TX2 (Cook Medical, Bloomington, IN, Amerikai Egyesült Államok) graftot ültettünk, majd az

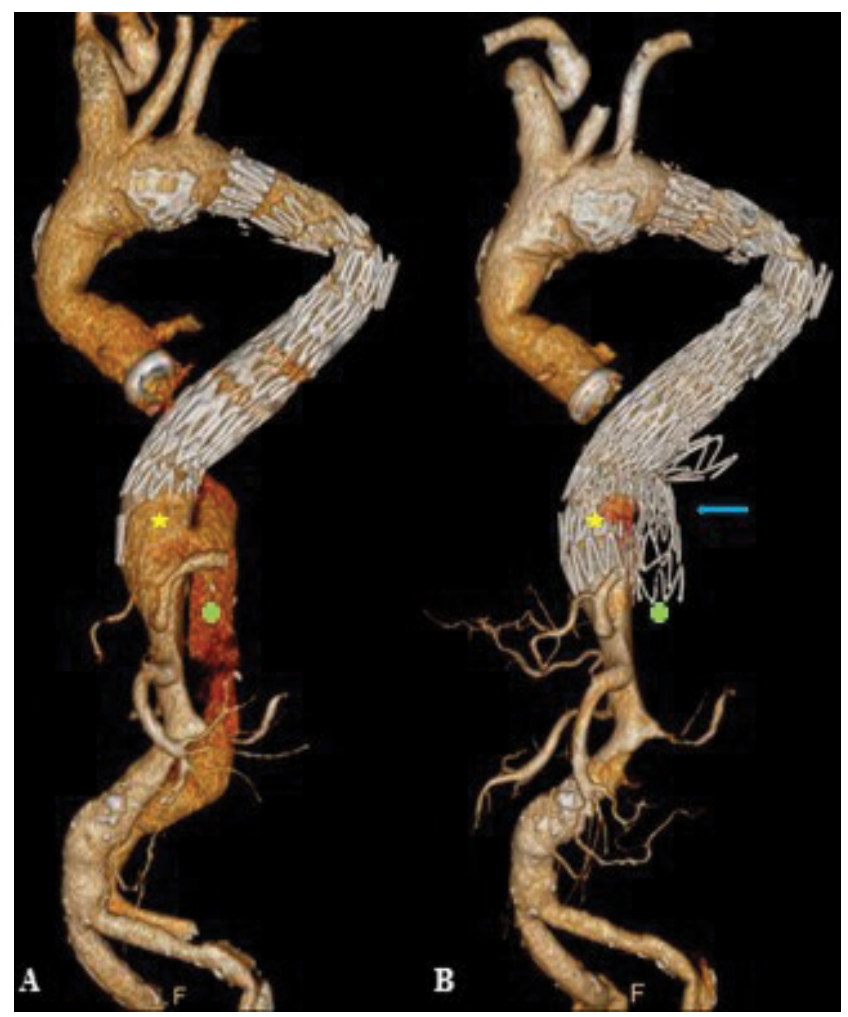

2. ábra 3D rekonstrukciós CTA a „candy-plug” beültetés elött (A) és 9 hónappal a beültetés után (B). Sárga csillag - valódi lumen; zöld kereszt - állumen; kék nyíl - „candy-plug” záróeszköz

CTA $=$ komputertomográfiás angiográfia 

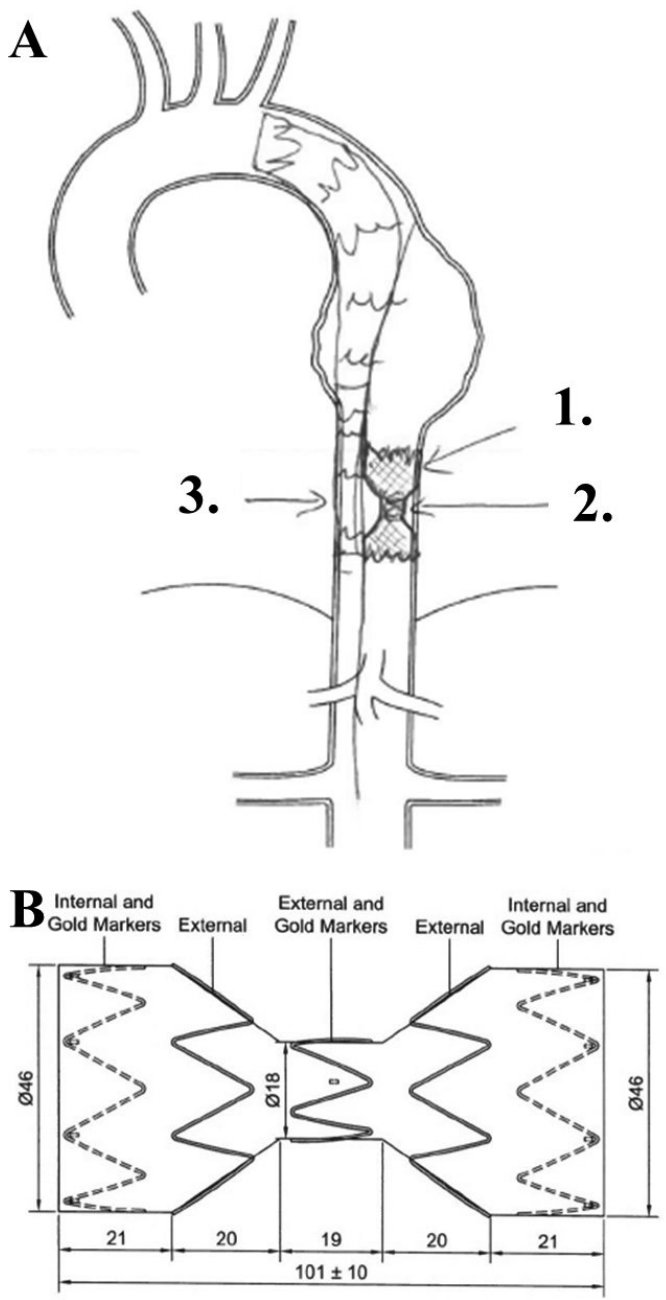

3. ábra

A „candy-plug” implantáció tervezési rajzai. A - az eszközök elhelyezkedésének sematikus ábrája: 1 . állumenben lévő „candyplug”; 2. „candy-plug”-ba ültetett occluder; 3. valódi lumenben lévő sztentgraft. B - a „candy-plug” eszköz sematikus rajza pontos méretekkel $(\mathrm{mm})$

állumenbe a valódi lumenbe ültetett graft distalis végéhez igazított Cook CMD „candy-plug”-ot (Cook Medical) helyeztünk be. A korábbi TEVAR-graftok folytatásaként behelyezett egyenes sztentgraft így lehetővé tette, hogy a valódi lument megóvjuk az esetleges kompressziótól, ugyanakkor az állumenbe helyezett, homokóra alakú „candy-plug” segítségével létrehoztunk egy egyszerüen lezárható, szúk részt az állumenben. Ezt követően a „candy-plug” elkeskenyedő centrális nyílását ZIP Occluderrel (Cook Medical) zártuk (3. ábra). A mútétet követő 4 . napon a bal lágyékban kialakult haematoma miatt reoperációt végeztünk. Az ezt követő posztoperatív időszak eseménytelen volt, a kontroll mellkas-has-kismedencei CT-angiográfia alapján a dissectio állumenében az áramlás megszúnt, részleges thrombosis alakult ki. A beteget a mútét utáni 10. napon panaszmentesen otthonába bocsátottuk. A beavatkozás után 3, majd 9 hónappal késóbb elvégzett kontroll-CT-angiográfia az állumen teljes elzáródását, a thoracoabdominalis aortatágulat stabilizálódását mutatta (1., 2. ábra).

A „candy-plug” módszer azokban az esetekben, amelyeknél a postdissectiós aneurysmát okozó, perzisztáló állumen vak tasakként van jelen, és megfelelő hosszúságú 'landing' zóna áll rendekezésre a sztentgraftok biztonságos pozicionálásához, hatékony, kis mútéti megterheléssel járó megoldás lehet az állumen lezárására, így a postdissectiós aneurysma további progressziójának megakadályozására.

Anyagi támogatás: A közlemény megírása anyagi támogatásban nem részesült.

Szerzôi munkamegosztás: H. L., J. V.: A közlemény megírása, irodalomkutatás. Cs.-N. Cs., S. F.: A képanyag elkészítése. Sz. Z., S. P.: A közlemény megírása. A cikk végleges változatát valamennyi szerző elolvasta és jóváhagyta.

Érdekeltségek: A szerzőknek nincsenek érdekeltségeik.

\section{Irodalom}

[1] Cheng D, Martin, J, Shennib H, et al. Endovascular aortic repair versus open surgical repair for descending thoracic aortic disease: a systematic review and meta-analysis of comparative studies. J Am Coll Cardiol. 2010; 55: 986-1001.

[2] Chavan A, Lotz J, Oelert F, et al. Endoluminal treatment of aortic dissection. Eur Radiol. 2003; 13: 2521-2534.

[3] Kusagawa H, Shimono T, Ishida M, et al. Changes in false lumen after transluminal stent-graft placement in aortic dissections: six years' experience. Circulation 2005; 111: 2951-2957.

[4] Li D, Ye L, He Y, et al. False lumen status in patients with acute aortic dissection: a systematic review and meta analysis. J Am Heart Assoc. 2016; 5: e003172. [Correction: J Am Heart Assoc. 2016; 5: e002068.]

[5] Tanaka A, Sakakibara M, Ishii H, et al. Influence of the false lumen status on clinical outcomes in patients with acute type B aortic dissection. J Vasc Surg. 2014; 59: 321-326.

[6] Song JM, Kim SD, Kim JH, et al. Long-term predictors of descending aorta aneurysmal change in patients with aortic dissection. J Am Coll Cardiol. 2007; 50: 799-804.

[7] Simring D, Raja J, Morgan-Rowe L, et al. Placement of a branched stent graft into the false lumen of a chronic type B aortic dissection. J Vasc Surg. 2011; 54: 1784-1787.

[8] Rohlffs F, Spanos K, Tsilimparis N, et al. Techniques and outcomes of false lumen embolization in chronic type $\mathrm{B}$ aortic dissection. J Cardivasc Surg. 2018; 59: 784-788.

[9] Kölbel T, Lohrenz C, Kieback A, et al. Distal false lumen occlusion in aortic dissection with a homemade extra-large vascular plug: the candy-plug technique. J Endovasc Ther. 2013; 20: 484-489.

(Hidi László dr.,

Budapest, Városmajor u. 68., 1122 e-mail: drhidilaszlo@gmail.com) 